\title{
Representações e práticas sobre o método de projetos e o ensino do vocabulário em Montes Claros (1920-1930) ${ }^{1}$
}

Geisa Magela Veloso*

Resumo

O artigo situa-se no âmbito da História Cultural e tem por objetivo discutir representações e práticas sobre o método de projetos e o ensino do vocabulário na escola primária e no curso normal. Como abordagem metodológica de pesquisa, foram consideradas ferramentas teóricas e conceituais produzidas pela historiografia. Como fontes documentais para acessar a realidade passada foram utilizados jornais, que circularam em Montes Claros, como também a Revista do Ensino - produzida pelo governo de Minas Gerais para disseminar princípios e ideias inovadoras entre os professores. $O$ recorte temporal foi definido pelo intervalo circunscrito entre as décadas de 1920 e 1930, período marcado por movimentos reformadores e intensas transformações sociais, econômicas, políticas e culturais. A análise das fontes permitiu constatar que, em Montes Claros, por influência dos princípios da Escola Nova, o método de projetos passou a ser utilizado como abordagem para o ensino globalizado de diferentes conteúdos, dentre eles a ampliação do vocabulário, que deveria servir como recurso para comunicação e expressão.

Palavras-chave: Escola Nova; Representações e Práticas; Ensino do vocabulário; Método de Projeto.

\section{Introdução}

O artigo constitui-se como recorte de pesquisa situada no âmbito da História Cultural, que visa mapear práticas de ensino produzidas em Montes Claros. Tomando Chartier $(1990,2002)$ como referência teórica, compreendemos que a História Cultural é a história das representações do mundo social, representações que não são a realidade, mas matrizes geradoras de discursos e práticas.

Doutora em Educação pela UFMG. Professora do Departamento de Métodos e Técnicas da Universidade Estadual de Montes Claros -Unimontes. E-mail: velosogeisa@gmail.com 
O artigo tem por objetivo discutir representações e práticas sobre o método de projetos e o ensino do vocabulário, produzidas no âmbito da escola primária e do curso normal, em Montes Claros, cidade situada no norte do Estado de Minas Gerais. Como recorte temporal optamos por historiar o intervalo circunscrito entre as décadas de 1920 e 1930, período marcado por movimentos reformadores e por intensas transformações sociais, econômicas, políticas e culturais. Da perspectiva histórica, o período tomado como referência para nossas análises constitui-se como momento especialmente fértil, em que o Brasil produz intenso processo de reformas educacionais, em que o estado de Minas Gerais busca disseminar ideias e propostas para renovação das práticas de ensino.

A década de 1920 presencia o engajamento de setores intelectuais em diferentes manifestações culturais, que gestaram o ideário do Brasil moderno, em que o país experimentou o que os historiadores caracterizam como "aceleração da história" - processo explicado pela sequência de modificações na esfera econômica, política, educacional e cultural (ARAUJO, 2004). Ainda conforme a autora, a Semana de Arte Moderna, realizada em São Paulo, em 1922, é um marco privilegiado na reflexão sobre este Brasil moderno. Nos anos de 1920 e no início de 1930, as temáticas que predominam entre a intelectualidade é a da Reconstrução Nacional e da unidade nacional, que seriam produzidas pela cultura educacional de moral laica, cívica e literária. Neste contexto, a educação moderna era o veículo primordial para promover a formação cultural integral em uma sociedade que se modernizava (ARAUJO, 2004).

Em Minas Gerais, como consequência da disseminação de ideias e pressupostos renovadores da Escola Nova, em 1927-28, Francisco Campos propôs um amplo projeto de reforma do ensino, que incluiu o rompimento com o modelo pedagógico adotado e teve por eixo norteador a inovação metodológica.

Em Montes Claros, pesquisas de Veloso (2008) indicam que as décadas de 1920-1930 se constituem como um momento em que as discussões produzidas por sua Escola Normal Official adquirem uma dimensão pedagógica e visam orientar a renovação das práticas educativas, sobretudo relacionadas à disciplina, à alfabetização e ao ensino da linguagem. Tal perspectiva revela uma filiação teórica ao movimento reformador da Escola Nova e visava à instauração da modernidade pedagógica, sendo realizadas conferências pedagógicas e outras atividades, que objetivavam discutir questões que mereciam a atenção dos educadores e orientar comportamentos e ações da população.

Para analisar as representações sobre o ensino da língua no contexto montes-clarense, tomamos o jornal Gazeta do Norte como fonte documental; sendo que a Revista do Ensino foi tomada como referência para captar a sincronia entre o 
movimento local e as questões discutidas no âmbito do estado de Minas Gerais, de forma a analisar o discurso oficial e as orientações dirigidas às professoras.

O modo de organização do jornal Gazeta do Norte é típico da Imprensa Brasileira nesse período, em que a sobrevivência da pequena empresa jornalística dependia da opinião dos seus leitores. Segundo Zicman (1985), até o período de 1945/50, a Imprensa Brasileira constituiu-se, basicamente, de pequenas empresas, com gestão improvisada, capitais e negócios limitados, primando-se por suas funções políticas. Segundo a autora, essa "Imprensa de Opinião", caracterizou-se pelo posicionamento apaixonado e claramente delimitado do ponto de vista político. Dessa forma, a imprensa tornou-se instrumento ativo de formação da opinião pública, ultrapassando a simples função de "espelho da realidade". O jornalismo era quase um exercício literário, sendo que a partir da década de 1950, a "Imprensa de Opinião" cede espaço para a "Imprensa de Informação" - constituindo uma pretensa objetividade, pela negação das características ideológicas e políticas, marcantes do período anterior (ZICMAN, 1985, p. 91).

Refletindo características de seu tempo, o jornal Gazeta do Norte se autodenominava como "semanário independente, literário e noticioso". Não tinha por prioridade a publicidade de fatos e ocorrências do dia a dia; mais do que isso, o jornal pretendia a formação de uma opinião esclarecida sobre temas e questões a ele contemporâneas, contribuindo para a construção de uma nova mentalidade. Dessa forma, o jornal assumiu a bandeira da educação, promoveu campanhas, disseminou práticas e concepções, conferiu visibilidade para as discussões ocorridas no âmbito da Escola Normal de Montes Claros, conclamou a população a se educar, a participar do debate e a favorecer a educação das novas gerações. No jornal, eram feitos chamamentos para a população, foram publicadas matérias pedagógicas e transcrições de conferências proferidas, dentre outros textos educativos e informativos.

A opção pelo jornal como fonte documental se processou por sua proficuidade e possibilidade de acesso à realidade. Conforme Barros (2004) e Vainfas (1997), o olhar direcionado para fontes não oficiais se deu pelo alargamento da concepção de fonte, no âmbito da História Cultural, que vislumbrou novas formas de ver, escrever e pensar a história, produzindo uma visão menos rígida e menos estereotipada da realidade. Conforme os autores, essa renovação produziu uma ampliação do campo de trabalho do historiador, que passou a fazer novos questionamentos e buscar uma nova problematização da realidade, não privilegiando documentos convencionais e se preocupando com o comum e o peculiar, com as opiniões e sentimentos expressos por experiências subjetivas e individuais narradas pelos sujeitos da história.

Ao focalizarmos a análise da realidade em pessoas comuns, apoiamo-nos em Le Goff, o qual afirma que, ao desenvolver o seu ofício, o historiador não deve ter 
por foco apenas os grandes homens e seus feitos igualmente grandiosos. Na constituição da memória coletiva deve-se considerar, também, a experiência do homem comum, inscrita em lugares e fontes não oficiais e não institucionais. Ainda para Le Goff, "devemos trabalhar de forma que a memória coletiva sirva para a libertação e não para a servidão dos homens” (2003, p. 471).

Ao tomar o jornal Gazeta do Norte como fonte documental consideramos que, ao produzir as notícias e disseminar determinado conjunto de informações e saberes, a imprensa se apresenta como mediadora entre o público e a realidade social que deseja mostrar. E, ao dar a ler os acontecimentos, o jornal dissemina representações que visam produzir a adesão de seu público leitor, modelando e disciplinando seu comportamento, seu modo de pensar, de ser e de entender a realidade. Ao analisar as publicações do jornal tornou possível captar orientações para o ensino da língua produzidas no contexto da Escola Normal Official de Montes Claros. As representações produzidas deixam clara a preocupação com a implementação de novas metodologias para o ensino da linguagem, dentre elas a utilização do método de projetos para uma abordagem interdisciplinar de diferentes conteúdos escolares.

A utilização do método de projeto para organização do ensino é uma abordagem proposta pela Escola Nova, contexto pedagógico no qual, também, é indicada a necessidade de renovação das práticas de ensino da linguagem. Nesse contexto, o artigo se organiza-se em dois movimentos. Inicialmente, apresentamos os eixos da renovação pedagógica pretendida para o ensino da linguagem, com foco no ensino do vocabulário, que foram disseminados no âmbito da Revista do Ensino-MG e do jornal Gazeta do Norte, em Montes Claros. Posteriormente, analisamos concepções de ensino da linguagem proposta pelo movimento escolanovista.

\section{Escola Nova e o trabalho com o vocabulário}

No contexto da Reforma Francisco Campos (1927-1928), o governo mineiro utilizou a Revista do Ensino como órgão oficial para disseminar ideias, princípios educativos, orientações pedagógicas e propostas para a renovação do ensino. A Revista foi criada pelo Regulamento do Ensino, que em seu artigo 479 indica o seu objetivo - estava "destinada a orientar, estimular e informar os funcionários do ensino e os particulares interessados em assumptos com este relacionados" (REVISTA DO ENSINO, 1925, p. 1).

Tendo sua primeira edição publicada em 1925, a revista contava com uma seção noticiosa, que divulgava ocorrências de Minas Gerais, do Brasil e outros países; mas, também, uma parte doutrinária, que se dirigia ao professorado e visava harmonizar seus esforços e conferir-lhe acesso aos conhecimentos correntes relati- 
vos ao ensino (REVISTA DO ENSINO, 1925, p. 1). No período em que consultamos a revista - entre os anos de 1925 e 1935 - foram publicadas diversas matérias de educadores mineiros, sínteses de aula, artigos traduzidos de outras revistas, trabalhos de interesse didático e educativo, sendo perceptível a influência da Escola Nova nestas diferentes matérias publicadas.

Ao estabelecer comparação entre os conteúdos disseminados nas matérias do jornal Gazeta do Norte e nos artigos da Revista do Ensino, Veloso (2008) constatou a atualidade das publicações ocorridas em Montes Claros. Ao assumir uma missão educativa e associar-se à Escola Normal Official de Montes Claros, o jornal possibilitou que princípios pedagógicos que guiavam as modernas propostas educativas pretendidas pelo governo mineiro pudessem circular entre a população de Montes Claros e região Norte-Mineira. A influência dos princípios educativos da Escola Nova, nos discursos e práticas disseminados pela Escola Normal Official de Montes Claros, é percebida a partir de 1932 e se amplia com a instalação do Curso de Aplicação, no ano de 1933, em que os professores do Curso Normal propõem novas formas de trabalho, ensino e produção de conhecimentos pedagógicos ${ }^{2}$.

Por influência do movimento da Escola Nova, o jornal Gazeta do Norte discute o trabalho com a linguagem e a aplicação dos princípios da psicologia à educação. Dentre as publicações do jornal, encontra-se artigo de Idoleta Maciel, aluna do curso de aplicação da Escola Normal Official de Montes Claros, em que o estudo do vocabulário é considerado como conteúdo a ser trabalhado na escola, em função da sua importância para a vida social. Na discussão, é destacado o valor da linguagem como instrumento de comunicação, que permite ao ser humano a exteriorização do que sente e pensa. A aluna lembra que:

É de uma grandeza inestimável o papel da linguagem nas manifestações da vida humana. Por ella transmitimos nossas experiências e recebemos as dos outros. A linguagem permite ao homem rever os tesouros de sabedoria legados pelas gerações passadas. Esta vasta seara de experiências, que maior realce e valor oferece à humanidade hodierna, não é esforço de um indivíduo, nem de uma geração, é o fructo do labor coletivo dos espíritos que já uma vez trabalharam e daqueles que ainda o fazem (MACIEL, 1933a, p. 1).

A linguagem era vista como instrumento de comunicação e transmissão de conhecimento, o que tornava necessária uma transformação das práticas escolares, para possibilitar à criança condições para exercitarem sua linguagem e ampliarem o vocabulário. Dentre essas condições é destacada a necessidade de motivação dos alunos.

Como somente pensamos quando nos encontramos diante uma situação problemática, é necessário que o professor, para despertar e activar o pensamento do alumno, forneça-lhe uma motivação que parta de uma interrogação que porá os alunos deante de um problema a resolver, fazendo surgir o necessário interesse (MACIEL, 1933a, p. 1). 
A dificuldade da criança em produzir significações para as palavras era tributada ao convívio social e à qualidade das experiências vividas no ambiente familiar.

Quanto ao vocabulário limitado pode ser devido a um campo de experiência reduzido, contato com pessôas e cousas que não requerem grande numero de palavras, e também devido a um descuido. Essa pobreza de vocabulário tende a estreitar a área da visão mental da criança. O vocabulário infantil recebe o influxo do lar, isto é, a contribuição dos paes, irmãos e criados, na sua formação. É no ambiente familiar que a criança inicia a aquisição do seu vocabulário, devendo por isso os paes esmerarem-se em ser bons educadores. Além dos paes há também a influencia das criadas, pessôas que mantêm convivencia continua com as crianças (MACIEL, 1933b, p. 1).

Para superar as dificuldades advindas do empobrecimento da linguagem, ampliar o conhecimento e possibilitar condições para a comunicação eficiente, a escola precisava desenvolver estratégias para ampliação do vocabulário dos alunos.

[A escola] tem pois que aumentar o vocabulário dessas crianças, tornando-o preciso e claro. Este aumento não deve ser feito por meio de listas de palavras, por as que não têm uso corrente na vida são facilmente esquecidas. Os livros e pessôas são insuficientes para dar vocabulário; o vocabulário perfeito é o activo, em que o alumno aprende palavras para aplical-as no commercio da vida (MACIEL, 1933b, p. 1).

Para ampliar a eficiência do vocabulário da criança, a escola precisa trabalhar a linguagem, enfatizando a significação das palavras, para possibilitar à criança a liberdade de pensar e expressar o que pensa. Para a pedagogia nova havia uma inversão na concepção de linguagem, que é compreendida como instrumento de comunicação, como conjunto de signos que se combinam para transmitir uma mensagem de um emissor para um receptor. Pela lógica da pedagogia tradicional, a linguagem era tomada como expressão de pensamento e fundamentava-se na ideia de que as pessoas não se expressam bem porque não pensam. No entanto, $o$ movimento renovador produziu uma inversão dessa perspectiva.

Antigamente diziam que o indivíduo tinha linguagem porque pensava e hoje dizemos que este pensa porque tem linguagem; portanto, quanto mais preciso for este vocabulário, mais liberdade tem elle de pensar. Para que a escola consiga esse objetivo deve apresentar-lhe as cousas juntamente ao seu significado, dar-lhe exercícios de linguagem, cujas palavras tenham uso corrente, dando margem à investigação do próprio alumno. $\mathrm{O}$ professor não deve ocupar se somente em expor a lição, interrompendo o alumno quando este deseja falar, porque assim torna-se um elemento desintegrador da linguagem. O professor fará o alumno falar constantemente, limitando-se apenas em oriental-o. Não deve nunca organizar phrases para os alunos completarem, pois isto os torna incapazes de falar correntemente proporcionando-lhes dificuldades de linguagem. É necessário que o professor incorpore ao seu espirito este valor do discurso consecutivo (MACIEL, 1933b, p. 1).

O discurso pedagógico indica claramente a necessidade de se produzir situações didáticas adequadas para o trabalho com a linguagem, de forma que a criança 
desenvolvesse habilidade para se expressar. Visando orientar as práticas educativas, Idoleta Maciel destaca a necessidade de aproximar o ensino das práticas de uso cotidiano da linguagem, trabalhar as "cousas" e suas significações para que as aulas não se tornem interrogatórios, mas se constituam como situações discursivas e oportunidades de desenvolvimento da linguagem.

$\mathrm{Na}$ vida, as nossas idéas não são externadas somente quando somos interrogados. Assim não deve o professor usar interrogatórios exagerados habituando o alumno a falar quase sempre por monossyllabos, em phrases curtas. Não poderá também o orientador transformar o objetivo da sua aula que é exercitar a linguagem do alumno, em aula de correção de erros, pois adviria certa timidez no falar. Essa correção deve ser feita sem causar inhibição, estorvo ou embaraço na actividade mental da criança.

[...] Aprender uma língua não é simplesmente transmitir pensamentos. Compreender é a tarefa primordial e básica deste ensino, eliminando assim o psitacismo (MACIEL, 1933b, p. 1).

No contexto montes-clarense é possível perceber o esforço para incorporar as diretrizes e princípios escolanovistas aos discursos destinados aos professores e às práticas desenvolvidas pelos alunos na sala de aula. Para a Escola Nova era importante que a escola criasse situações para vincular escola e vida social; o aluno deveria se constituir como centro do processo educativo, as práticas deveriam valorizar os alunos e favorecer o desenvolvimento de sua autonomia na aquisição do conhecimento.

Ao analisar o contexto mais amplo, constatamos que as discussões ocorridas em Montes Claros dialogam com as questões publicadas na Revista do Ensino. Em1925, ano de criação da Revista do Ensino, o periódico discute o trabalho com a linguagem e o desenvolvimento do vocabulário na escola. Em seu volume 08, o professor Claudio Brandão afirma ser o vocabulário um elemento vital para o conhecimento de qualquer idioma. "São as palavras o estôjo em que se talha o pensamento, a tela mysteriosa em que ele se contórna e se matiza; e, si ellas lhe não constituem a matéria prima, servem, ao menos, para external-o e amplifical-o" (BRANDÃO, 1925a, p. 209).

Para o professor Claudio Brandão, o professor poderia criar a sua própria didática e o seu método de ensino, lembrando que os processos de ensino renovados "[...] se baseam nos treis meios que a pedagogia sempre considerou os mais suaves e eficientes, a saber, a conversação, a leitura e a composição" (BRANDÃO, 1925b, p. 246, grifo do autor).

No entanto, em sua argumentação, o professor considera que a simples realização de atividades de conversação, leitura e composição não eram suficientes para a efetiva aprendizagem. 
Para terem plena proficuidade, cumpre dar aos exercícios de conversação a máxima naturalidade. Nelles, o professor, exercendo um papel principalmente directivo, esforçar-se-á para formar o que se poderia chamar de dialogismo do alumno, isto é, o poder e o saber conversar, dote precioso na vida pratica e no convívio social (1925b, p. 246-247, grifo do autor).

Ainda conforme o professor Brandão, a professora poderia criar situações para motivar o exercício da conversação, por meio da leitura de poesias e histórias, fazer perguntas sobre as impressões dos alunos acerca do texto lido e, após a conversa, propor atividades escritas. Ao discutir a prática da recitação de poemas, a revista afirma que os recitativos agradavam aos meninos e aos pais, mas o seu objetivo não era esse, mas o de ampliar o vocabulário, a provisão de ideias e os pensamentos bons.

Ainda em relação à relevante da conversação para o aprendizado, no ano de 1926, a Revista do Ensino publica artigo adaptado da revista americana Normal Instructor and Primary Plans, tecendo críticas às práticas de ensino desenvolvidas na escola. Isso porque os professores começam a interrogar, corrigir e repreender acerca dos usos da linguagem, de forma que, até a criança mais "viva e conversadeira" se torna uma pessoa apagada na sociedade. Para sanar este defeito do ensino, a revista sugere que, no lugar de corrigir a criança, o professor deveria tomar nota mentalmente dos erros mais repetidos, para se corrigi-los em outra ocasião. A revista também sugere o desenvolvimento de lições de cortesia, lições de informação (descrever, falar o que sabe sobre determinado assunto), lições de observação (observar e descrever objetos, pessoas, etc.) (REVISTA DO ENSINO, 1926).

Para a revista, "qualquer assumpto, inteligentemente aproveitado, pode fornecer material para uma boa lição", reforçando a necessidade de não produzir uma abordagem artificial das conversas. "[...] O fimm da composição oral é ensinar à criança a falar com naturalidade e fluência e communicar seus pensamentos aos outros, enriquecendo, assim, sua experiência” (REVISTA DO ENSINO, 1926, p. 50).

Em seus estudos, Valdemarin e Campos constataram a preocupação com a renovação do ensino da linguagem, a partir do movimento da Escola Nova. Ao analisar manual didático destinado à escola primária, publicado em 1956, as autoras destacam atividades que incorporam o ideário escolanovista, valorizam a autonomia do aluno, sua participação ativa no processo de conhecimento, bem como o recurso aos aspectos lúdicos e construtivos. Conforme as autoras, alguns conteúdos do ensino primário são mais permeáveis a esses objetivos, sendo esse o caso da língua portuguesa e da história pátria, para as quais são sugeridas atividades de pesquisa, criação de textos com discussões coletivas. 
O ensino da linguagem nas primeiras séries tem como objetivo o domínio da expressão, a clareza e a simplicidade e por isso deve iniciar-se oralmente com diálogos sobre o cotidiano, valendose de jogos e brincadeiras que garantam a motivação. A aprendizagem da linguagem escrita começa com a cópia de palavras, a partir das quais são destacadas as sílabas, combinações, inserções em frases, etc. (VALDEMARIN; CAMPOS, 2007, p. 350).

Percebe-se, nesses discursos, uma preocupação com a linguagem das crianças e sua utilização nos processos de comunicação. A abordagem didática se orienta pela concepção linguística dominante nesse período, ou seja, a linguagem como instrumento de comunicação.

\section{Método de projetos e 0 ensino da linguagem}

No contexto da renovação das metodologias de ensino, no ano de 1932 , por ocasião das comemorações do centenário de fundação da cidade de Montes Claros, a sua Escola Normal Official propôs o desenvolvimento de um projeto didático que culminou com a realização de auditório e exposição de trabalhos pelos alunos das classes anexas e do Curso Normal. A proposição do projeto como metodologia de ensino é uma abordagem defendida pelo movimento da Escola Nova. Conforme Lourenço Filho (1978), a proposta de projetos foi originalmente denominada de home-projects, pela qual se pretendia destacar a importância educativa de tarefas de execução livre pelos alunos, em casa, como também a necessidade de que as atividades realizadas na escola atendessem a propósitos, cuja forma e direção seriam definidos pelo projeto. Ainda conforme o autor, a proposição teórica do sistema de projetos foi realizada por John Dewey, ainda em 1895, sendo defendida com base na escola experimental e orientada em função do atendimento aos interesses dos alunos. Em suas teorizações, Dewey procurou responder aos argumentos daqueles que acreditavam que o ensino baseado em atividades interessadas dos alunos poderia destruir o sentimento de esforço e o cultivo da vontade. No entanto, para Dewey, o bom ensino somente seria possível quando os alunos, sob conveniente direção, pudessem realizar as atividades propostas, movendo-se por intenções que estabelecessem relações entre impulsos e desejos, propósitos definidos, ideais e valores (LOURENÇO FILHO, 1978).

Em Montes Claros, visando dar visibilidade para o avanço educacional do município e a atualidade das práticas pedagógicas da sua Escola Normal Official, o jornal Gazeta do Norte transcreve matéria publicada pelo jornal A Pátria. Na referida publicação, é destacada a influência do professor Francisco Floriano de Paula, considerado como um "educador perfeitamente familiar com os progressos 
da psycologia e da methodologia educacionaes" (A PATRIA, apud GAZETA DO NORTE, 1932b, p. 1). A matéria ainda afirma que:

Em logar de se ensinar as creanças exclusivamente por meio de predicas, de palestras, de lições decoradas, o methodo de projectos vem satisfazer à tendência profunda da alma infantil para a atividade, mas uma actividade orientada por um proposito, ligada de élo em élo por um pensamento constructor, que obriga a reflexão e desperta a iniciativa.

No programma de Montes Claros, o dr Paula empregou em larga escala o methodo de projectos. Os alumnos fizeram innumeras excursões para conhecer a vida da cidade, foram a mercados, a fabricas, a escolas, a fonte de abastecimentos dagua, a prisões, a consultórios de profissionaes, a pontos pitorescos e históricos, etc. (A PATRIA, apud JORNAL GAZETA DO NORTE, 1932b, p. 1).

Ainda em 1932, o inspetor Sebastião Zimbres tece elogios ao trabalho do professor Francisco Floriano de Paula e destaca "o aperfeiçoamento na formação integralizadora da experiência de suas educandas" produzido pelo trabalho até então desenvolvido. "Pude percebel-o pela leitura das monographias já apresentadas, de algumas provas mensais e dos relatórios e criticas do trabalho pratico realizado no curso primário. Manuseei um grande numero de projectos inteiramente executados" (ZIMBRES, 1932, p. 1). O inspetor escolar Jason de Moraes também confere destaque para a renovação metodológica produzida na Escola Normal Official de Montes Claros e afirma que o professor Francisco Floriano de Paula "operou no espirito de suas alumnas transformação tão sensível que o Methodo de Projectos tem a mais ampla e natural execução na Escola Normal de Montes Claros". Segundo o inspetor, "as innumeras palestras que assisti e aulas de socialização pelas alumnas robustecem em meu espirito a firme convicção de que o trabalho escolar realiza-se nesta casa de instrucção com observância dos mais modernos processos pedagógicos" (MORAES, 1932, p. 2).

No projeto didático desenvolvido na Escola Normal Official de Montes Claros em comemoração ao centenário do município, cada turma trabalhou com uma área do conhecimento, explorando a cultura montes-clarense, a geografia e os aspectos econômicos, políticos, judiciários, eclesiásticos, policiais e educacionais do município, a higiene, a geografia, o comércio, a indústria, a economia, o abastecimento de água, a vida rural e a história da cidade. Também foram explorados temas relacionados à aritmética, operações, geometria, música e canto, ciências naturais e educação física. Foram desenvolvidos estudos relacionados aos usos e costumes, atividades domésticas e psicologia do povo montes-clarense. Além dos processos de investigação, também foram realizadas atividades artísticas de cartonagem, modelagem, desenhos, exercícios de alteres e trabalhos manuais (GAZETA DO NORTE, 1932, p. 1). No entanto, a leitura dos documentos disponíveis não nos possibilitou a identificação de um problema da realidade, para o qual os alunos buscariam respos- 
tas. O que se percebe é a utilização de um evento local - o centenário do município como elemento mobilizador das ações de aprendizagem propostas pelos professores.

Dentre as diversas atividades desenvolvidas no referido projeto, o estudo de gramática e linguagem também foi contemplado, o que coube a duas turmas do Curso Normal. As alunas do $1^{0}$ ano trabalharam com "vocabulário, descripções e biografia de Montes Claros"; enquanto que as alunas do $2^{\circ}$ ano desenvolveram "investigação sobre vocabulário, construções gramaticaes, folk-lore do município", além de canto, músicas e canções regionais (GAZETA DO NORTE, 1932a, p. 1).

A proposição do ensino globalizado e orientado por um problema da realidade encontra consonância nos princípios da Escola Nova. Conforme Lourenço Filho, a aplicação dos princípios da Escola Nova implica uma transformação radical dos procedimentos usuais, de forma a considerar quatro princípios educativos. De um modo, o princípio de que "o pensamento se origina de uma situação problemática", em contraposição à antiga crença de que o espírito, a inteligência e a razão eram formados independentemente da ação real e da vida verdadeira, com seus interesses, desejos e propósitos. De outra forma, "o princípio da experiência real anterior", que compreende as situações vividas por cada indivíduo como importantes na resolução dos problemas que surgem. Como consequência tem-se "o princípio da prova final”, em que se considera que, se o pensamento é resultante de uma situação problemática, a sua função é a de resolver essa situação; e "o princípio da eficácia social”, ao considerar o valor prático dos atos, mas, também, a sua eficácia na vida social (LOURENÇO FILHO, 1978, p. 202).

Segundo Lourenço Filho, a escola tradicional não atendia a essa realidade, pois organiza-se pelo ensino verbal, em que se trabalhava o pensamento puro, abstrato. No entanto, para as práticas renovadas, "o ponto de partida do pensamento é uma ação problemática, uma tentativa para um empreendimento" (1978, p. 202). Assim, a Escola Nova exige condições concretas, pois o pensamento não funciona no abstrato e não se processa por geração espontânea. Os símbolos do pensamento precisam estar ligados a episódios reais para que tenham significação. "O que conserva, equilibra e desenvolve o pensamento é a sua eficácia, ou o poder que tenha em ser aplicado para a solução de situações problemáticas" (1978, p. 203).

E o método de projeto atendia a essa necessidade educativa. Lourenço Filho (1978) lembra que os projetos não visavam apenas às atividades manuais, mas também às atividades intelectuais e, como a globalização é a essência do sistema de projetos, há expressões variadas em cada assunto, em desenhos e construções, mas, há também, projetos puramente intelectuais, visando à disciplina do pensamento.

A defesa do método de projetos em Montes Claros se alicerça na possibilidade de aquisição de conhecimentos e motivação do aluno para a aprendizagem de diversos conteúdos e habilidades. Pela possibilidade de integração desses pontos de 
vista é que o método de projetos se apresentava adequado para o trabalho com os conteúdos escolares, neles incluindo o desenvolvimento da linguagem e da capacidade de expressão de pensamento.

\section{Considerações finais}

Nesse artigo, discutimos algumas faces da modernização pretendida para o ensino da linguagem nas décadas de 1920-1930, em que o movimento renovador da Escola Nova propôs a mudança nas práticas de ensino, a partir de uma nova concepção de língua e linguagem. Esse é um contexto em que a linguagem não poderia ser compreendida como mera expressão de pensamento.

Conforme Travaglia, ao compreender a linguagem como expressão do pensamento, entende-se que os problemas de expressão se relacionam à dificuldade de organização do pensamento; no que se alicerça a defesa de que a expressão se constrói no interior da mente e a sua exteriorização é apenas uma tradução do que pensa 0 falante. Isso significa dizer que, da capacidade de organizar o pensamento dependerá a sua exteriorização por meio de uma linguagem organizada e articulada.

Com Bakhtin, podemos afirmar que a concepção de linguagem como expressão do pensamento seja limitadora do fenômeno linguístico, por considerar que o conteúdo a exprimir pudesse constituir-se no interior da mente e fora da expressão. Para o autor, o equívoco se encontra na crença de que, tanto o conteúdo a exprimir como a sua objetivação externa são criados a partir de um único e mesmo material. Não existe atividade mental sem expressão, a linguagem não se forma no interior, ao contrário, ela é organizada no exterior e é determinada pelas condições da enunciação. "Não é a atividade mental que organiza a expressão, mas, ao contrário, é a expressão que organiza a atividade mental, que a modela e determina sua orientação" (1997, p. 112).

Para Lourenço Filho, o pensamento se origina de uma situação problema, sendo esta uma ideia que se contrapõe a antigas crenças de que a inteligência e o pensamento se constituiriam de forma independente da ação real e da vida verdadeira, com seus desejos, interesses e propósitos. Se o pensamento não se forma isolado da ação, é preciso agir para pensar. "Nestas condições, os símbolos do pensamento devem estar ligados a episódios reais para que tenham significação. Fora disso, será devaneio ou mera expressão emocional" (LOURENÇO FILHO, 1978, p. 202). Nisso consiste a renovação pretendida para o ensino da linguagem naquele momento histórico.

Nas representações disseminadas pelos defensores da renovação, são identificadas críticas ao ensino verbalista e afastado dos interesses e de cotidiano da 
criança. Por orientação dos princípios da Escola Nova, a renovação pretendida implica a necessidade de considerar as peculiaridades da criança e apoiar o ensino dos conteúdos em realidades concretas. Há ainda uma preocupação de que o ensino se processasse em contextos significativos, sendo o método de projetos considerado como uma abordagem renovadora e adequada à aprendizagem ativa e ajustada aos interesses dos alunos. O método de projetos também permite desenvolver práticas de ensino globalizado, em que os conteúdos de diferentes disciplinas poderiam ser explorados pelos alunos, dentre elas o vocabulário e a linguagem da criança.

A análise das práticas com o método de projetos em Montes Claros indica a incorporação de algumas inovações propostas pela Escola Nova em termos de atividades desenvolvidas pelos alunos - excursões, visitas, pesquisas, desenhos, modelagem, construções de maquetes e outros trabalhos manuais. Para o trabalho com a linguagem também se percebe que as orientações se apoiam na utilização das situações cotidianas para desenvolver as habilidades de uso da linguagem. No entanto, a dificuldade de rompimento com a tradição pode ser percebida na estrutura formal da proposta desenvolvida em cada disciplina, que divide as atividades, estruturando-as de modo a compor os conteúdos do programa de ensino determinado oficialmente.

\section{Representations and practices on project method and theteaching of vocabulary in Montes Claros (1920-1930)}

\section{Abstract}

The article is in the scope of Cultural History and aims to discuss representations and practices on the project method and the teaching of vocabulary in elementary school and in the normal course. As methodological approach, were considered theoretical and conceptual tools produced by historiography. As documentary sources to access the past reality newspapers were used, circulated in Montes Claros, as well as the Journal of Education - produced by the government of Minas Gerais to disseminate principles and innovative ideas among teachers. The time frame was defined range limited between the 1920s and 1930s, a period marked by reform movements and intense social, economic, political and cultural. The analysis of the sources have revealed that in Montes Claros, influenced by the principles of the New School, the project method started to be used as an approach to global teaching with different contents including the expansion of vocabulary which should serve as a resource for communication and expression.

Keywords: New School. Representations and practices. Teaching vocabulary. Project Method. 


\section{Notas}

1 A pesquisa contou com apoio financeiro da Fundação de Amparo à Pesquisa do Estado de Minas GeraisFAPEMIG, a quem agradecemos. O projeto de pesquisa foi aprovado pelo Comitê de Ética da Unimontes, sob parecer 2522, em conformidade com a Resolução 196/1996, do Conselho Nacional de Saúde.

2 Sob influência do movimento escolanovista, em 1933, a Escola Normal de Montes Claros cria a Revista Escola Nova, que, conforme o jornal Gazeta do Norte, era dirigida pelas "gentis e intelligentes senhoritas Idoleta Maciel e Feliciana Athayde, do Curso de Aperfeiçoamento da Escola" e se constituiu como "órgão official para suas aspirações e desenvolvimento intelectual” (GAZETA DO NORTE, 1933, p. 1). Nesse período, o jornal Gazeta do Norte instituiu a Columna Pedagógica, que passou a publicar artigos produzidos pelas alunas do Curso de Aplicação e de professores do Curso Normal.

\section{Fontes documentais}

BRANDÃO, Cláudio. Pedagogia - O valor educativo do vocabulário. Revista do Ensino: Orgam Official da Inspectoria da Instrucção, Belo Horizonte, a. I, n. 8, out. 1925a. (Arquivo Público Mineiro - Belo Horizonte -MG).

A escola proporciona um convívio intelligente entre mestres e discípulos. Belo Horizonte: Revista do Ensino: Orgam Official da Inspectoria da Instrucção, Belo Horizonte a. I, n. 9, dez. 1925b. (Arquivo Público Mineiro - Belo Horizonte-MG).

GAZETA DO NORTE. A nova educação no interior do Brasil. Jornal Gazeta do Norte: semanário literário e independente, Montes Claros, a. XV. nº 839, 19 de nov. 1932 (1932b) (Acervo do CPDOC - Centro de Pesquisa e Documentação da Unimontes).

. Na Escola Normal Official. Jornal Gazeta do Norte: semanário literário e independente, Montes Claros, a. XV. nº 832, 8 out. 1932 (Acervo do CPDOC - Centro de Pesquisa e Documentação da Unimontes).

Escola Nova. Jornal Gazeta do Norte: semanário literário e independente, Montes Claros, a. XV, nº 868, 24 jun. 1933 (Acervo do CPDOC - Centro de Pesquisa e Documentação da Unimontes).

MACIEL, Idoleta. A linguagem como instrumento de communicação. Jornal Gazeta do Norte: semanário literário e independente, Montes Claros, ano XV, nํ 856, 25 mar. 1933a. Columna pedagógica. (Acervo do CPDOC - Centro de Pesquisa e Documentação da Unimontes).

A linguagem como instrumento de comunicação. Transcrito de A Patria. Jornal Gazeta do Norte: semanário literário e independente, Montes Claros, a. XV. nํ 857. 01 deabril, 1933b. Columna pedagógica. (Acervo do CPDOC - Centro de Pesquisa e Documentação da Unimontes).

MORAES, Jason. Pela Instrucção. Termo de Asssitencia Technica. Jornal Gazeta do Norte: semanário literário e independente, Montes Claros, a. XV, no 842, 17 dez. 1932 (Acervo do CPDOC - Centro de Pesquisa e Documentação da Unimontes).

REVISTA DO ENSINO: Orgam Official da Inspectoria da Instrucção. Editorial. Belo Horizonte, a. I. no 01. 8 mar. 1925. (Acervo do Arquivo Público Mineiro - Belo Horizonte-MG).

. Lições de conversação. Belo Horizonte, a. II, n. 11, fev. 1926. (Artigo adaptado da Revista Americana Normal Instructorand Primary Plans). (Acervo do Arquivo Público Mineiro - Belo Horizonte-MG). 
. Como recitar. Belo Horizonte, a. V, n. 41, jan. 1930. (Acervo do Arquivo Público Mineiro - Belo Horizonte-MG).

ZIMBRES, Sebastião. Pela Instrucção. Escola Normal Official. Jornal Gazeta do Norte: semanário literário e independente, Montes Claros, a. XV, nº 839, 26 nov. 1932. (Acervo do CPDOC - Centro de Pesquisa e Documentação da Unimontes).

\section{Referências}

ARAUJO, Marta Maria. A educação tradicional e a educação nova no 'Manifesto dos pioneiros'. In: XAVIER, Maria do Carmo (Org). Manifesto dos pioneiros da educação: um legado educacional em debate. Rio de Janeiro: Editora FGV; Fumec, 2004. p. 131-146.

BAKHTIN, M. Marxismo e filosofia da linguagem. 7. ed. Trad. Michel Lahud e Yara Frateschi Vieira. São Paulo: Hucitec, 1997.

BARROS, José D’Assunção. O campo da história: especialidades e abordagens. Petrópolis-RJ: Vozes, 2004.

CHARTIER, Roger. História Cultural: entre práticas e representações. Trad. Maria Manuela Galhardo. Rio de Janeiro: Berthand do Brasil, 1990.

. À beira da falésia: história entre certezas e inquietudes. Porto Alegre: Editora da Universidade/UFRGS, 2002.

LE GOFF, Jacques. Historia e memória. 5. ed. São Paulo: Editora da Unicamp, 2003.

LOURENÇO FILHO, Manoel Bergstrom. Introdução ao estudo da escola nova: bases, sistemas e diretrizes da Pedagogia contemporânea. 12. ed. São Paulo: Melhoramentos; Rio de Janeiro: Fundação Nacional de Material Escolar, 1978.

TRAVAGLIA, Luiz Carlos. O ensino de gramática numa perspectiva textual interativa. SOLAR Ambiente Virtual de Aprendizagem. Ceará: Universidade Federal do Ceará- UFC. Disponível em: <https://www.google.com.br/\#q=O+ensino+de+gram\%C3\%A1tica+numa+perspectiva+textu al+interativa>. Acesso em: 14 out. 2013.

VAINFAS, Ronaldo. História das mentalidades e história cultural. In.: CARDOSO, Ciro Flamarion; VAINFAS, Ronaldo (Org.). Domínios da história: ensaios de teoria e metodologia. Rio de Janeiro: Campus. 1997. p. 127-162

VALDEMARIN, Vera Teresa; CAMPOS, Daniela Gonçalves dos Santos. Concepções pedagógicas e método de ensino: O manual didático Processologia na Escola Primária. Revista Paidéia, v. 17, n. 38, p. 343-356, 2007. Disponível em: <https://www.google.com.br/\#q=Concep\%C3\%A7\%C3\%B 5es+pedag\%C3\%B3gicas+e+m\%C3\%A9todo+de+ensino $\% 3 \mathrm{~A}+\mathrm{O}+$ manual+did\%C3\%A1tico+Proc essologia+na+Escola+Prim\%C3\%A1ria>. Acesso em: 10 fev. 2014.

VELOSO, Geisa Magela. A missão desanalfabetizadora do jornal Gazeta do Norte em Montes Claros (1818-1938). Tese (Doutorado em Educação) - Faculdade de Educação, Universidade Federal de Minas Gerais, Belo Horizonte, 2008.

ZICMAN, Renée Barata. História através da imprensa: algumas considerações metodológicas. Projeto História-Revista do Programa de Estudos Pós-graduação em História e do Departamento de História. São Paulo: PUC/SP. 1985. p. 89-102. 